\title{
Khảo sát một số hoạt tính sinh học trong cao chiết methanol từ rễ tơ và rễ tự nhiên cây bá bệnh (Eurycoma Longifolia Jack)
}

\author{
Trần Thu Trang, Phạm Bích Ngọc, Chu Nhật Huy, \\ Hoàng Thị Thu Hằng, Nguyễn Trung Nam, Chu Hoàng Hà* \\ Viện Công nghệ sinh học, Viện Hàn lâm Khoa học \& Công nghệ Việt Nam, \\ 18 Hoàng Quốc Việt, Hà Nội, Việt Nam \\ Nhận ngày 10 tháng 10 năm 2016 \\ Chỉnh sửa ngày 26 tháng 10 năm 2016; Chấp nhận đăng ngày 28 tháng 6 năm 2017
}

\begin{abstract}
Tóm tắt: Bá bệnh (Eurycoma longifolia Jack) là loại thảo dược dùng điều trị bệnh sốt rét, ung thư, tiểu đường, rối loạn chức năng tình dục và tăng cường sức khỏe ở nam giới. Năm 2012, chúng tôi đã báo cáo phương pháp tạo rễ tơ của cây Bá bệnh với mục đích tạo nguồn nguyên liệu ổn định, đáp ứng nhu cầu làm thuốc. Trong bài báo này, chúng tôi khảo sát hoạt tính sinh học của cao chiết methanol từ rễ tơ và rễ tự nhiên cây Bá bệnh. Kết quả cho thấy cao chiết methanol từ rễ tơ và rễ tự nhiên ức chế sản xuất cytokine gây viêm IL-6 kích thích bởi Lipopolysaccharide (LPS) ở dòng tế bào $\mathrm{THP}-1$ với $\mathrm{IC}_{50}$ tương ứng là 3,6 và $6,6(\mu \mathrm{g} / \mathrm{ml})$. Cao chiết methanol từ rễ tơ và rễ tự nhiên có hoạt tính gây độc tế bào ung thư ở mức trung bình trên các dòng tế bào HepG2, LU-1, MCF-7 với $\mathrm{IC}_{50}$ tương ứng là $77,4,61,1,88,2(\mu \mathrm{g} / \mathrm{ml})$ và $63,8,46,2,54,8(\mu \mathrm{g} / \mathrm{ml})$. Tuy nhiên, cả hai loại cao chiết nghiên cứu đều không có khả năng ức chế quá trính peroxy hoá lipid $\left(\mathrm{IC}_{50}>100\right)$.
\end{abstract}

Tùu khoá: Bá bệnh (Eurycoma longifolia), hoạt tính kháng viêm, hoạt tính gây độc tế bào, hoạt tính chống oxy hoá.

\section{Mở đầu}

Bá bệnh (Eurycoma longifolia Jack), thuộc họ Simaroubaceae, là một loài thực vật có hoa thuộc họ thanh thất, có nguồn gốc Indonesia, Malaysia, Việt Nam, Campuchia, Myanmar, Lào và Thái Lan. Là cây thuốc quan trọng ở các quốc gia Đông Nam Á, do có dược tính rộng như hoạt tính kháng viêm, chống ung thư và chữa sốt rét [1-6], rễ của cây này được sử dụng như là một loại thuốc làm tăng lượng

\footnotetext{
*Tác giả liên hệ. ĐT.: 84-912175636.

Email: chuhoangha@ibt.ac.vn

https://doi.org/10.25073/2588-1140/vnunst.4478
}

testosterone ở nam giới, làm chậm quá trình mãn dục nam [7-10]. Ở Việt Nam, cây mọc tự nhiên ở miền Trung, ven rừng còi Kon tum, Đồng Nai đến Phú Quốc [11]. Cây cũng được tìm thấy tại Vườn quốc gia Bái Tử Long từ năm 2000. Hiện nay, nguồn rễ của cây Bá bệnh chủ yếu từ việc thu hái ở rừng dẫn đến cạn kiệt nguồn gen. Những năm gần đây, cùng với xu hướng chung trên thế giới, ở nước ta bắt đầu nghiên cứu nuôi cấy sinh khối từ rễ tơ. Rễ tơ là một bệnh ở thực vật được gây ra bởi quá trình tương tác giữa vi khuẩn Agrobacterium rhizogenes và tế bào vật chủ. $\mathrm{Vi}$ khuẩn đất gram âm chuyển đoạn $\mathrm{ADN}$ (T-ADN) từ (Ri) plasmid vào hệ gen của cây bị xâm nhiễm, đoạn T-ADN này mang gen mã hóa sinh tổng hợp 
auxin và cytokinin làm tăng khả năng tạo các lông rễ [12]. Việc thiết lập hệ thống nuôi cấy rễ tơ cho các cây dược liệu có nhiều ưu điểm vượt trội như chủ động quá trình sản xuất, nâng cao hàm lượng hoạt chất, tối ưu hoá quy trình chiết xuất sẽ góp phần khắc phục các hạn chế trong sản xuất truyền thống cũng như thể hiện được tính cập nhật về nghiên cứu và phát triển công nghệ mới trong nuôi cấy tế bào. Ngoài ra, việc nghiên cứu hoạt tính sinh học của sinh khối rễ tơ không những giúp sử dụng dược liệu một cách hiệu quả mà trên cơ sở đó còn có thể xác định được những hoạt chất quý để từ đó điều khiển quá trình nuôi cấy làm tăng tích luỹ các hoạt chất đó nhằm cung cấp nguồn dược liệu quý trong điều trị bệnh. Đã có rất nhiều công trình nghiên cứu trên thế giới cho thấy rễ tự nhiên của cây Bá bệnh có nhiều hoạt tính tốt. Tuy nhiên, các bằng chứng khoa học về hoạt tính sinh học của rễ tơ còn chưa được công bố. Chính vì vậy, mục tiêu của nghiên cứu này là xác định và so sánh hoạt tính kháng viêm, gây độc tế bào ung thư và khả năng chống oxy hoá của rễ tơ và rễ tự nhiên của cây Bá bệnh. Kết quả nghiên cứu là cơ sở cho các nghiên cứu sâu tiếp theo về hoạt tính sinh dược học của các hợp chất từ rễ tơ và rễ tự nhiên của cây Bá bệnh.

\section{Vật liệu và phương pháp nghiên cứu}

\subsection{Vật liệu nghiên cứu}

Nguyên liệu thực vật:

Rễ tự nhiên của cây Bá bệnh được thu thập tại vườn Quốc gia Bái Tử Long, khu Bảo tồn thiên nhiên Đồng Sơn - Kỳ Thượng, Hoành Bồ, Quảng Ninh. Rễ tơ của cây Bá bệnh được cung cấp bởi Phòng Công nghệ Tế bào Thực vậtViện Công nghệ sinh học- Viện Hàn lâm Khoa học và Công nghệ Việt Nam.

\section{Các dòng tế bào:}

Các dòng tế bào ung thư do GS. J. M. Pezzuto, trường Đại học Hawaii và GS. Jeanette Maier, trường Đại học Milan, Italia cung cấp. Dòng tế bào đại thực bào người THP-1 do GS.
T. Kishimoto, trường Đại học Osaka, Nhật Bản cung cấp.

\section{Chuột nghiên cưu:}

Chuột thuần chủng dòng $\mathrm{BALB} / \mathrm{c}$ khoẻ mạnh, không mắc bệnh được cung cấp bởi Phòng Thử nghiệm sinh học, Viện Công nghệ sinh học, Viện Hàn lâm Khoa học và Công nghệ Việt Nam.

\section{Thiết bị:}

Cân phân tích, máy đo OD Microplate Reader, máy đọc ELISA và các thiết bị phòng thí nghiệm khác.

\section{Hóa chất:}

Môi trường nuôi cấy các dòng tế bào ung thu, FBS, TCA, SRB; Trolox, Cucumine, (Sigma Aldrich); Dimethylsulfoside (DMSO) (Fisher Scientific); Đệm phosphat hoặc KCl; Acid tricloacetic (TCA, Fisher); Acid thiobarbituric (TBA) (Sigma Aldrich); $\mathrm{FeSO}_{4}, \mathrm{H}_{2} \mathrm{O}_{2}$.

Môi trường nuôi cấy dòng tế bào đại thực bào ở người THP-1, RPMI 1640 (GIBCO), $10 \% \mathrm{FBS}, 100 \mu \mathrm{g} / \mathrm{ml}$ streptomycin, $100 \mathrm{U} / \mathrm{ml}$ penicillin, Dimethylsulfoside (DMSO), đệm phosphat PBS; trypan blue stain 0,4\%, LPS (LPS, Escherichia coli 055: B5) (Sigma Aldrich). Đĩa 96, 48 giếng nhựa (Corning), pippette (Eppendorf). Các dung môi, hóa chât thông thường được cung cấp bởi các hãng Sigma, GIBCO, Invitrogen. Bộ kit ELISA (R\&D Systems).

\subsection{Phương pháp nghiên cứu}

\section{Phuoong pháp chuẩn bị mẫu thư}

Cân $5 \mathrm{~g}$ mẫu khô, xay nhuyễn ngâm methanol trong bể siêu âm $(500 \mathrm{ml} \mathrm{x} 3$ lần $)$. Ly tâm 5000 vòng trong 5 phút, thu dịch loại bỏ cặn. Cô quay dịch đuổi dung môi, thu nhận cao chiết.

Phương pháp nuôi cấy tế bào THP-1 và xác định hàm lượng IL-6

Dòng tế bào THP-1 được nuôi cấy dưới dạng đơn lớp trong môi trường nuôi cấy RPMI 1640 theo các phương pháp đã được công bố 
trước đây $[13,14]$. Dòng tế bào được nuôi trong đĩa 48 giếng, chứa $5 \times 10^{5}$ tế bào/ml. Lấy $1 \mathrm{ml}$ tế bào thêm vào $1 \mu \mathrm{l}$ mẫu thử ở các nồng độ $(3000,10000,30000,60000 \mu \mathrm{g} / \mathrm{ml})$ thì nồng độ mẫu chỉ còn là $(3,10,30,60 \mu \mathrm{g} / \mathrm{ml})$. Ủ hỗn hợp ở $37^{\circ} \mathrm{C}, 5 \% \mathrm{CO}_{2}$ trong 30 phút trước khi được kích thích với $1 \mu \mathrm{g} / \mathrm{mL}$ LPS (Sigma, Tokyo, Japan). Dịch nổi được thu sau 24 giờ. Nồng độ cytokine IL-6 của tế bào đại thực THP-1 được xác định bằng ELISA (Quantikine ELISA của $R \& D)$ theo hướng dẫn của nhà sản xuất. Số liệu được biểu diễn dưới dạng giá trị trung bình của ít nhất 3 lần lặp lại. Giá trị $\mathrm{IC}_{50}$ sẽ được xác định nhờ vào phần mềm máy tính ImageJ. Khả năng sống sót của tế bào được xác định bằng phương pháp MTT theo phương pháp đã được công bố trước đây [15].

Phép thử sinh học xác định tính độc tế bào (cytotoxic assay)

Phép thử này được thực hiện theo phương pháp của Monks (1991) [16]. Mẫu thử pha trong DMSO $10 \%$ được đưa vào các giếng của khay 96 giếng để có nồng độ nồng độ 100 $\mu \mathrm{g} / \mathrm{ml}, 20 \mu \mathrm{g} / \mathrm{ml} ; 4 \mu \mathrm{g} / \mathrm{ml} ; 0.8 \mu \mathrm{g} / \mathrm{ml} ; 0.16$ $\mu \mathrm{g} / \mathrm{ml}$. Tế bào ung thư được duy trì liên tục ở các điều kiện tiêu chuẩn. Sau khi tế bào phát triển đến pha $\log$, sẽ được thêm vào các giếng $3.10^{4}$ tế bào/ml và để chúng phát triển trong vòng từ 2 ngày. Một khay 96 giếng khác không có chất thử nhưng có TBUT sẽ được sử dụng làm đối chứng ngày 0 . Sau 1 giờ, đĩa đối chứng ngày 0 sẽ được cố định tế bào bằng Trichloracetic acid - TCA.

Sau giai đoạn phát triển trong tủ ấm $\mathrm{CO}_{2}$, tế bào được cố định vào đáy giểng bằng $\mathrm{TCA}$ trong 1 giờ, được nhuộm bằng $\mathrm{SRB}$ trong 30 phút ở $37{ }^{\circ} \mathrm{C}$. Đổ bỏ $\mathrm{SRB}$ và các giếng thí nghiệm được rửa 3 lần bằng acetic acid rồi để khô trong không khí ở nhiệt độ phòng. Cuối cùng, sử dụng $10 \mathrm{mM}$ unbuffered Tris base để hòa tan lượng $\mathrm{SRB}$ đã bám và nhuộm các phân tử protein, đưa lên máy lắc đĩa lắc nhẹ trong 10 phút và sử dụng máy ELISA Plate Reader (BioRad) để đọc kết quả về hàm lượng màu của chất nhuộm SRB qua phổ hấp phụ ở bước sóng 515 nm. Khả năng sống sót của tế bào khi có mặt chất thử sẽ được xác định thông qua công thức sau:

$$
\begin{gathered}
\% \text { sống sót }=\frac{[\mathrm{OD}(\text { chất thử })-\mathrm{OD}(\text { ngày } 0)] \times 100}{\mathrm{OD}(\text { đối chứng âm })-\mathrm{OD}(\text { ngày } 0)} \\
\% \text { ức chế }=100 \% \text { - \% sông sót }
\end{gathered}
$$

Các phép thử được lặp lại 3 lần để đảm bảo tính chính xác. Ellipticine luôn được sử dụng như là chất đối chứng dương. DMSO $10 \%$ luôn được sử dụng như đối chứng âm. Giá trị $\mathrm{IC}_{50}$ sẽ được xác định nhờ vào phần mềm máy tính TableCurve.

Phương pháp xác định khả năng ức chế quá trính peroxy hoá lipid (thử nghiệm MDA)

Được thực hiện theo phương pháp của Stroev EA, Makarova VG (1998) [17], Jelili A Badmus et al., (2011) [18] và của Viện Dược liệu - Bộ Y Tế (2006), có sự thay đổi cho phù hợp với điều kiện của phòng thí nghiệm. Tách não chuột và nghiền đồng thể trong dung dịch đệm phosphat $(\mathrm{pH}=7.4)$ theo tỉ lệ $1: 10$ ở nhiệt độ $0-4^{\circ} \mathrm{C}$. Lấy $1 \mathrm{ml}$ dịch đồng thể thêm vào 0,1 $\mathrm{ml}$ mẫu thử ở các nồng độ $(2000,400,80,16$ $\mu \mathrm{g} / \mathrm{ml}$ ) và $0,8 \mathrm{ml}$ đệm phosphat thêm $0.1 \mathrm{ml}$ hệ Penton $\left(\mathrm{FeSO}_{4} 0.1 \mathrm{mM}: \mathrm{H}_{2} \mathrm{O}_{2} 15 \mathrm{mM}\right.$ theo tỉ lệ $1: 1)$ vừa đủ $2 \mathrm{ml}$ thì nồng độ mẫu chỉ còn là $(100,20,4,0.8 \mu \mathrm{g} / \mathrm{ml})$. Ủ hỗn hợp ở $37^{\circ} \mathrm{C}$ trong 15 phút. Dừng phản ứng bằng $1 \mathrm{ml}$ acid tricloacetic $10 \%$. Li tâm 12000 vòng trong 5 phút. Lấy dịch trong cho phản ứng với $1 \mathrm{ml}$ acid thiobarbituric $0,8 \%$ (theo tỉ lệ $2: 1$ ). Ủ ở nhiệt độ $100^{\circ} \mathrm{C} 15$ phút. Làm lạnh và tiến hành đo ở bước sóng $\lambda=532 \mathrm{~nm}$. Trolox được sử dụng làm chất đối chiếu tham khảo. Tính toán kết quả theo công thức tính phần trăm hoạt tính chống oxi hoá $(\mathrm{HTCO}) \mathrm{HTCO}(\%)=\left[\left(\mathrm{OD}_{\mathrm{C}}-\right.\right.$ $\left.\left.\mathrm{OD}_{\mathrm{T}}\right) / \mathrm{OD}_{\mathrm{C}}\right] \times 100\left(\mathrm{OD}_{\mathrm{C}}\right.$ : Mật độ quang học của giếng chứng không có mẫu thử; $\mathrm{OD}_{\mathrm{T}}$ : Mật độ quang học của mẫu thử).

\section{Phuoong pháp thống kê}

Số liệu được xử lý và phân tích thống kê bằng kiểm định Student's $t$-tests. Kết quả có ý nghĩa thống kê khi trị số $P<0.05$ tại mức $\alpha=0.05$. 


\section{Kết quả và thảo luận}

Hoạt tính úc chế IL-6 trên dòng tế bào đại thực bào THP-1 của cao chiết methanol tù rễ̂ tơ và rễ tụ nhiên

Hoạt tính kháng viêm của một số alkaloid của rễ tơ cây Bá bệnh đã được thử nghiệm trên dòng tế bào đại thực bào chuột RAW264.7 [19]. Kết quả cho thấy, một số alkaloid của rễ tơ cây Bá bệnh có khả năng ức chế việc sản xuất IL-6, một cytokine gây viêm, trên dòng tế bào RAW264.7 kích thích bởi LPS [19]. Do đó, trong nghiên cứu này chúng tôi tiếp tục khảo sát hoạt tính kháng viêm của cao chiết methanol từ rễ tơ và rễ tự nhiên Bá bệnh trên dòng tế bào đại thực bào người THP-1. Khả năng sống sót của dòng tế bào THP-1 không bị ảnh hưởng khi được xử lý với hai cao chiết methanol từ rễ tơ và rễ tự nhiên (Hình $1 \mathrm{~A}$ ). Dòng tế bào THP-1 được xử lý với các nồng độ cao chiết methanol rễ tơ và rễ tự nhiên khác nhau $(3,10,30,60$ $\mu \mathrm{g} / \mathrm{ml}$ ) trong 30 phút trước khi kích thích bằng LPS $(1 \mu \mathrm{g} / \mathrm{ml})$ và dịch nuôi cấy tế bào được thu sau $24 \mathrm{~h}$ để xác định hàm lượng IL-6 tạo ra. Kết quả ở hình $1 \mathrm{~B}$ cho thấy, cao chiết methanol rễ tơ và rễ tự nhiên đã ức chế việc sản xuất IL-6 ở dòng tế bào THP-1 của người kích thích bởi LPS và sự ức chế này phụ thuộc vào nồng độ liều. Cao chiết methanol rễ tơ và rễ tự nhiên ức chế sản xuất $\mathrm{IL}-6$ với $\mathrm{IC}_{50}$ lần lượt là 3,6 và 6,6 $(\mu \mathrm{g} / \mathrm{ml})$. Một nghiên cứu khác về hoạt tính kháng viêm của rễ tự nhiên cây Bá bệnh cho thấy, cao chiết hydroalcoholic cây Bá bệnh của Malaysia thể hiện hoạt tính kháng viêm ở tất cả các nồng độ thử nghiệm $(25,50,100,250,500$ và $1000 \mathrm{mg} / \mathrm{ml}$ ) trên tế bào máu người theo phương pháp ổn định màng tế bào máu (human red blood cell membrane stabilization) và hoạt tính thể hiện phụ thuộc vào nồng độ liều cao chiết [20]. Như vậy, cao chiết từ rễ Bá bệnh có hoạt tính kháng viêm tốt trên các dòng tế bào in vitro.

Bảng 1. Kết quả xác định giá trị IC50 của cao chiết methanol từ rễ tơ và rễ tự nhiên ức chế IL-6 trên dòng tế bào đại thực bào THP-1 của người

\begin{tabular}{|c|c|c|c|c|c|c|c|c|}
\hline \multirow{3}{*}{ STT } & \multirow{3}{*}{ Tên mẫu } & \multicolumn{6}{|c|}{ Úc chế IL-6 $(\mathrm{pg} / \mathrm{ml})$ tại nồng độ $(\mu \mathrm{g} / \mathrm{ml})$} & \multirow{3}{*}{$\begin{array}{c}\mathrm{IC}_{50} \\
(\mu \mathrm{g} / \mathrm{ml})\end{array}$} \\
\hline & & ĐC (-) & 0 ĐC (+) & 3 & 10 & 30 & 60 & \\
\hline & & PBS & \multicolumn{5}{|c|}{ LPS $(1 \mu \mathrm{g} / \mathrm{ml})$} & \\
\hline 1 & $\begin{array}{l}\text { Cao methanol } \\
\text { của rễ tơ }\end{array}$ & 0 & 458 & 265 & 172 & 117 & 27 & 3,6 \\
\hline 2 & $\begin{array}{l}\text { Cao methanol } \\
\text { của rễ tự nhiên }\end{array}$ & 0 & 458 & 289 & 192 & 84 & 24 & 6,6 \\
\hline
\end{tabular}
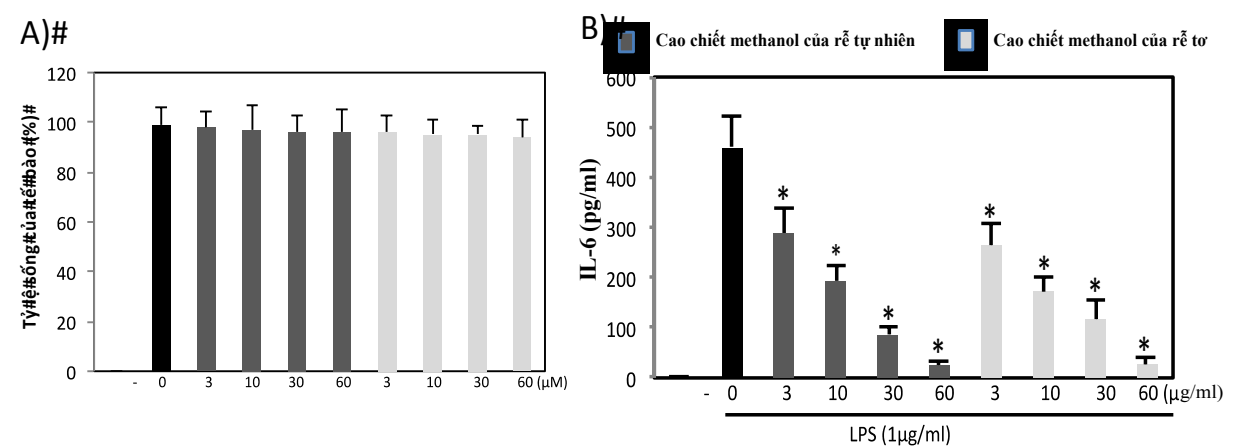

Hình 1. A) Ảnh hưởng cao chiết methanol rễ tơ và rễ tự nhiên lên khả năng sống sót của dòng tế bào THP-1. B) Cao chiết methanol của rễ tơ và rễ tự nhiên ức chế sản xuất IL-6 trên dòng tế bào THP-1 kích thích bởi LPS. 


\section{Khả năng gây độc tế bào ung thu in vitro}

Phép thử này được thực hiện theo phương pháp của Monks (1991) [16]. Theo tiêu chuẩn của Viện ung thư quốc gia Hoa Kỳ (National Cancer Institute - NCI), cặn chiết được coi có hoạt tính tốt với $\mathrm{IC}_{50} \leq 20 \mu \mathrm{g} / \mathrm{ml}$. Kết quả về khả năng gây độc tế bào ung thư in vitro của cao chiết methanol rễ tơ và rễ tự nhiên Bá bệnh được thể hiện ở bảng 2.

Bảng 2. Kết quả xác định giá trị $\mathrm{IC}_{50}$ của cao chiết methanol rễ tơ và rễ tự nhiên

\begin{tabular}{|c|c|c|c|c|c|c|c|}
\hline \multirow{2}{*}{ STT } & \multirow{2}{*}{ Tên mẫu } & \multirow{2}{*}{$\begin{array}{c}\text { Dòng tế } \\
\text { bào }\end{array}$} & \multicolumn{4}{|c|}{ \% Úc chế tại nồng độ $(\mu \mathrm{g} / \mathrm{ml})$} & \multirow{2}{*}{$\begin{array}{c}\mathrm{IC}_{50} \\
(\mu \mathrm{g} / \mathrm{ml})\end{array}$} \\
\hline & & & 100 & 20 & 4 & 0.8 & \\
\hline \multirow{3}{*}{1} & \multirow{3}{*}{$\begin{array}{l}\text { Cao chiết methanol } \\
\text { của rê̂ tơ }\end{array}$} & Hep-G2 & 61,2 & 16,8 & 0,6 & $-0,6$ & 77,4 \\
\hline & & LU-1 & 64,4 & 28,3 & 12,3 & 5,7 & 61,1 \\
\hline & & MCF-7 & 54,7 & 13,3 & 2,4 & $-9,9$ & 88,2 \\
\hline \multirow{4}{*}{2} & \multirow{4}{*}{$\begin{array}{l}\text { Cao chiết methanol } \\
\text { của rễ tự nhiên }\end{array}$} & Hep-G2 & 75,9 & 18,8 & 2,4 & 5,2 & 63,8 \\
\hline & & LU-1 & 70,8 & 36,6 & 7,1 & 4,5 & 46,2 \\
\hline & & MCF-7 & 75,1 & 26,8 & 9,1 & 6,9 & 54,8 \\
\hline & & Hep-G2 & 99,72 & 71,89 & 52,31 & 20,58 & 0,46 \\
\hline \multirow[t]{2}{*}{3} & Ellipticine & LU-1 & 97,67 & 72,70 & 51,52 & 23,65 & 0,43 \\
\hline & & MCF-7 & 98,01 & 78,89 & 50,82 & 19,77 & 0,44 \\
\hline
\end{tabular}

Kết quả ở bảng 1 cho thấy, cao chiết methanol rễ tơ và rễ tự nhiên thể hiện hoạt tính kháng ung thư ở mức trung bình trên cả ba dòng tế bào ung thư Hep-G2 $\left(\mathrm{IC}_{50}\right.$ rễ tơ $=77,4$ $\left.\mu \mathrm{g} / \mathrm{ml} ; \mathrm{IC}_{50 \text { rễ tư nhiên }}=63,8 \mu \mathrm{g} / \mathrm{ml}\right) ; \mathrm{LU}-1\left(\mathrm{IC}_{50}\right.$ rễ to $=61,1 \mu \mathrm{g} / \mathrm{ml} ; \mathrm{IC}_{50}$ rễ tự nhiên $\left.=46,2 \mu \mathrm{g} / \mathrm{ml}\right)$; MCF-7 $\left(\mathrm{IC}_{50}\right.$ rễ tơ $=88,2 \mu \mathrm{g} / \mathrm{ml} ; \mathrm{IC}_{50}$ rễ tự nhiên $=$ $54,8 \mu \mathrm{g} / \mathrm{ml})$. Chất đối chứng dương Ellipticine hoạt động ổn định trong quá trình thí nghiệm. Các kết quả trên là chính xác với $\mathrm{r}^{2} \geq 0,99$. Một nghiên cứu khác của nhóm Nurhanan và cộng sự đã đánh giá hoạt tính gây độc tế bào cao chiết methanol thu từ rễ tự nhiên cây Bá bệnh Malaysia. Kết quả cho thây, cao chiết methanol có hoạt tính gây độc tế bào với dòng tế bào $\mathrm{KB}$ $\left(\mathrm{IC}_{50}=20 \mu \mathrm{g} / \mathrm{ml}\right), \mathrm{RD}\left(\mathrm{IC}_{50}=17,9 \mu \mathrm{g} / \mathrm{ml}\right)$,
MCF-7 $\left(\mathrm{IC}_{50}=8,6 \mu \mathrm{g} / \mathrm{ml}\right), \mathrm{CaOV}-3\left(\mathrm{IC}_{50}=9,2\right.$ $\mu \mathrm{g} / \mathrm{ml}$ [ [21]. Như vậy, hoạt tính gây độc tế bào có thế phụ thuộc vào các loại cao chiết khác nhau và rễ dược liệu có nguồn gốc khác nhau.

\section{Hoạt tính chống oxy hóa}

Do hiện nay vẫn chưa có công bố nào về hoạt tính chống oxy hóa của rễ tơ Bá bệnh nên chúng tôi khảo sát hoạt tính chống oxy hóa của rễ tơ so với rễ tự nhiên Bá bệnh. Sử dụng phương pháp thử nghiệm khả năng chống oxy hóa dập tắt gốc tự do bằng phép thử peroxy hoá lipid màng tế bào, chúng tôi thu được kết quả về hoạt tính chống oxy hóa của rễ tơ và rễ tự nhiên Bá bệnh được thể hiện ở bảng 3 .

Bảng 3. Kết quả xác định hoạt tính chống oxi hóa (\%)

\begin{tabular}{cccc}
\hline $\begin{array}{c}\text { Nồng độ } \\
(\mu \mathrm{g} / \mathrm{ml})\end{array}$ & $\begin{array}{c}\text { Cao chiết rễ } \\
\text { tơ }\end{array}$ & $\begin{array}{c}\text { Cao chiết } \\
\text { rễ tự nhiên }\end{array}$ & Trolox \\
\hline 100 & 12,2 & 12,8 & 82,8 \\
20 & 10,2 & 9,4 & 59,2 \\
4 & 7,7 & 7,1 & 39,5 \\
0,8 & 4,3 & 2,6 & 12,2 \\
$\mathrm{IC}_{50}(\mu \mathrm{g} / \mathrm{ml})$ & $>100$ & $>100$ & 10,2 \\
\hline
\end{tabular}


Kết quả ở bảng 3 cho thấy, hàm lượng malonyl dialdehyd (là sản phẩm của quá trình peroxy hoá lipid màng tế bào tạo ra trong tế bào) chưa bị ảnh hưởng nhiều bởi hai loại cao chiết này với các nồng độ thử $(0,8 ; 4 ; 20$ và 100 $\mu \mathrm{g} / \mathrm{ml})$. Như vậy, cả hai loại rễ đều chưa thể hiện hoạt tính chống oxi hoá với giá trị $\mathrm{IC}_{50}$ $>100 \mu \mathrm{g} / \mathrm{ml}$ trong khi đó chất đối chứng là Trolox có $\mathrm{IC}_{50}$ là $10.2 \mu \mathrm{g} / \mathrm{ml}$. Năm 2013, một nghiên cứu cao chiết hydroalcoholic của cây Bá bệnh ở Malaysia thể hiện hoạt tính chống oxy hóa $\mathrm{DPHH}$ ở tất cả các nồng độ $(25,50,100$ và $250 \mu \mathrm{g} / \mathrm{ml})$ với $\mathrm{IC}_{50}=34,37 \mu \mathrm{g} / \mathrm{ml}[20]$. Như vậy, trong các nghiên cứu tiếp theo chúng tôi có thể sẽ sử dụng cao chiết của dung môi khác để khảo sát hoạt tính chống oxy hóa của rễ tơ và rễ tự nhiên cây Bá bệnh.

\section{Kết luận}

Cao chiết methanol rễ tơ và rễ tự nhiên cây Bá bệnh có khả năng ức chế (quá trình) sản xuất cytokine gây viêm IL-6 kích thích bởi LPS (1 $\mu \mathrm{g} / \mathrm{ml}$ ) ở dòng tế bào của người THP- 1 với $\mathrm{IC}_{50}$ tương ứng là 3,6 và $6,6(\mu \mathrm{g} / \mathrm{ml})$. Cả hai loại cao chiết này có hoạt tính gây độc tế bào ung thư ở mức trung bình trên các dòng tế bào HepG2, LU-1, MCF-7. Tuy nhiên, cả hai loại cao chiết nghiên cứu đều không có khả năng ức chế quá trình peroxy hoá lipid. Việc tìm hiểu và làm sáng tỏ cơ chế của các hoạt tính sinh học của hai cao chiết rễ Bá bệnh ở tế bào động vật là rất cần thiết.

\section{Lời cảm ơn}

Chúng tôi xin chân thành cảm ơn GS. T. Kishimoto, trường Đại học Osaka, Nhật Bản và PGS.TS. Đỗ Thị Thảo, phòng thử nghiệm sinh học, Viện Công nghệ sinh học đã giúp đỡ chúng tôi thực hiện công trình nghiên cứu này. Công trình này được hoàn thành với hỗ trợ kinh phí từ đề tài cán bộ trẻ năm 2017 (NCS. Trần Thu Trang).

\section{Tài liệu tham khảo}

[1] Phạm Bích Ngọc, Nguyễn Đình Trọng, Hoàng Hà, Lâm Đại Nhân, Chu Hoàng Hà. Nghiên cứu khả năng tạo rễ tơ của cây Bá bệnh (Eurycoma longifolia Jack) thông qua vi khuẩn agrobacterium rhizogenes. Tạp chí Khoa học và Công nghệ 50 (2012) 166.

[2] Wernsdorfer WH, Ismail S, Chan KL, Congpuong K, Wernsdorfer G. Activity of Eurycoma longifolia root extract against Plasmodium falciparum in vitro. Springer link 3 (2008) 23.

[3] Taylor WR, Hanson J, Turner GD, White NJ, Dondorp AM. Respiratory Manifestationsof Malaria Lung in Malaria. Chest J 142 (2012) 492.

[4] Ping CK, Amooru G, Damu KH, Tian SW. Cytotoxic and antimalarial constituents from the roots of Eurycoma longifolia. Bioorganic \& Medicinal Chiemistry 3 (2004) 537.

[5] Kuo PC, Shi, LS, Damu AG, Su CR, Huang CH, $\mathrm{Ke} \mathrm{CH}$, Wu JB, Lin AJ, Bastow KF Lee KH. Cytotoxic and antimalarial $\beta$-carboline alkaloids from the roots of Eurycoma longifolia. Journal of Natural Products 66 (2003)1324.

[6] Bhat R, Karim AA. Tongkat Ali (Eurycoma longifolia Jack): a review on its ethnobotany and pharmacological importance. Fitoterapia 81(2010) 669.

[7] Bin SL, Prashanta KD, Kit LC. Standardized quassinoid-rich Eurycoma longifolia extract improved spermatogenesis and fertility in male rats via the hypothalamic-pituitary-gonadal axis. Journal of Ethnopharmacology 3 (2013) 706.

[8] Low BS, Choi SB, Abdul Wahab H, Das PK, Chan KL. Eurycomanone, the major quassinoid in Eurycoma longifolia root extract increases spermatogenesis by inhibiting the activity of phosphodiesterase and aromatase in steroidogenesis. Journal of Ethnopharmacol 1(2013) 201.

[9] Ang HH, Ngai TH, Tan TH. Effects of Eurycoma longifolia Jack on sexual qualities in middle aged male rats. Phtomedicine 6-7 (2003) 590.

[10] Chen CK, Mohamad WMZ, Ooi FK, Ismail SB, Abdullah MR, George A, Supplementationof Eurycoma longifolia Jack Extract for 6 Weeks Does Not Affect Urinary Testosterone: Epitestosterone Ratio, Liver and Renal Functions in Male Recreational Athletes. International journal of Preventive Medicine 5 (2014) 728.

[11] Phạm Hoàng Hộ, NXB trẻ, Cây cỏ Việt Nam, TP. Hồ Chí Minh, 1998. 
[12] Guillon S, Trémouillaux-Guiller J, Pati PK, Rideau M, Gantet P. Hairy root research: recent scenario and exciting prospects. Curr Opin Plant Biol. 9 (2006) 341.

[13] Masuda K1, Kimura A, Hanieh H, Nguyen NT, Nakahama T, Chinen I, Otoyo Y, Murotani T, Yamatodani A, Kishimoto T. Aryl hydrocarbon receptor negatively regulates LPS-induced IL-6 production through suppression of histamine production in macrophages. Int Immunol 10 (2011) 637.

[14] Millrine D, Haruhiko M, Tei M, Dubey P, Kishan $\mathrm{N}$, Nakahama $\mathrm{T}$, Gemechu Y, Ripley $\mathrm{B}$, Kishimoto T. Immunomodulatory drugs inhibit TLR4 induced type-1 interferon production independently of Cereblon via suppression of the TRIF/IRF3 pathway. Int Immunol 5 (2016) 28.

[15] Hai Dang N, Choo YY, Tien Dat N, Hoai Nam N, Van Minh C, Lee JH. 7- Methoxy-(9H- $\beta$ Carbolin-1-il)-(E)-1-Propenoic Acid, a $\beta$ Carboline Alkaloid From Eurycoma longifolia, Exhibits Anti-Inflammatory Effects by Activating the Nrf2/Heme Oxygenase-1 Pathway. Journal of Cell Biochem. 117 (2016) 659.

[16] Monks A, Scudiero D, Skehan P, Shoemake R, Paull K, Vistica D, Hose C, Langley, Cronise JP, Campbell H, Mayo J, Boyd M. Feasibility of a high-flux anticancer drug screen using a diverse panel of cultured human tumor cell lines. Journal of National Cancer Institute 11 (1991) 757.

[17] Stroev EA, Makarova VG. Determination of lipid peroxidation rate in tissue homogenate labotory. Manual in Biochemistry (Moscow) (1998) 243.

[18] Jelili A. Badmus, Temitope O. Adedosu, John O. Fatoki, Victor A Adegbite, Oluwatosin A. Adarmoye and Oyeronke A Odunola. Lipid peroxidation inhibition and antiradical activities of some leaf fractions of Mangiferaindica. Acta Poloniae Pharmaceutica Drug Research, 68 (2011) 23.

[19] Ngoc PB, Binh PT, Dang NH, Trang TT, Ha CH, Minh CV, Lee JH, Dat NT. Anti-inflammatory bcarboline alkaloid from the hairy-root cultures of Eurycoma longifolia. Natural Product Research. 30 (2016)1360-5.

[20] Varghese CP, Ambrose C, Jin SC, Lim YJ and Keisaban T. Antioxidant and Anti-inflammatory Activity of Eurycoma Longifolia Jack, A Traditional Medicinal Plant in Malaysia. International Journal of Pharmaceutical Sciences and Nanotechnology 4 (2013) MS ID: IJPSN-524-12-VARGHESE

[21] Nurhanan M, Hawariah L, Ilham AM, Shukri M. Cytotoxic effects of the root extracts of Eurycoma longifolia Jack. Phytotherapy research 19 (2005) 994.

\title{
Examination (Evaluation) of Biological Activities of Methanolic Extracts from Hairy- and Natural- Roots of Eurycoma Longifolia Jack
}

\author{
Tran Thu Trang, Pham Bich Ngoc, Chu Nhat Huy, \\ Hoang Thi Thu Hang, Nguyen Trung Nam, Chu Hoang Ha \\ Institute of Biotechnology, Vietnam Academy of Science and Technology, \\ 18 Hoang Quoc Viet, Hanoi, Vietnam
}

\begin{abstract}
Eurycoma longifolia Jac, a medicinal herb, is used to treat malaria, cancer, diabetes and sexual dysfunction in human. In 2012, we reported the method of hairy-root culture of Eurycoma longifolia aiming to create a stable source of raw materials for the pharmaceutical need. In this study, we further examined the biological activities of the methanolic extracts from hairy- and natural- roots of Eurycoma longifolia. The results showed that the methanolic extracts from hairy- and natural-roots inhibited the production of IL-6 in THP-1 cells stimulated by lipopolysaccharide (LPS) with $\mathrm{IC}_{50}$ of 3.6 and $6.6(\mu \mathrm{g} / \mathrm{ml})$, respectively. Two methanolic extracts from hairy- and natural-roots had moderate cytotoxic activity against three human cancer cell lines, HepG2, LU-1, and MCF-7 with $\mathrm{IC}_{50}$ of 77.4, $61.1,88.2(\mu \mathrm{g} / \mathrm{ml})$ and $63.8,46.2,54.8(\mu \mathrm{g} / \mathrm{ml})$, respectively. However, both investigated extracts were incapable of inhibiting lipid peroxidation $\left(\mathrm{IC}_{50}>100\right)$.
\end{abstract}

Keywords: Antioxidant activity, anti-inflammatory activity, cytotoxic activity, Eurycoma longifolia. 